\title{
M-WebQuest Development: Reading Comprehension of Senior High School Students in Indonesia
}

\author{
https://doi.org/10.3991/ijet.v15i03.10628 \\ Hadriana Adanan, Mahdum Adanan ${ }^{(凶)}$ \\ Universitas Riau, Riau, Indonesia \\ mahdum@unri.ac.id \\ Tutut Herawan \\ Airlangga University, Surabaya, Indonesia
}

\begin{abstract}
M-WebQuest is a teaching model adapted from WebQuest created firstly by Bernie Dodge, where its development is used ADDIE model. This research aims to develop M-WebQuest to improve reading comprehension attainment of senior high school students Grade XI in Pekanbaru, Riau Indonesia. In gaining the feasibility of the developed M-WebQuest, 3 experts, 10 English teachers and 30 students were involved. Based on the given questionnaire analysis, the experts agree on the feasibility of created MWebQuest in terms of technical, content, material unit, and impacts of using MWebQuest on students and teachers. The English teachers and the students are also agree on the feasibility of created M-WebQuest in terms of interface screen, texts, and content. Overall, it can be concluded that M-WebQuest can be used for the learning activities of English Reading Comprehension subject.
\end{abstract}

Keywords-M-WebQuest; Development; Feasibility; Reading; Student.

\section{Introduction}

For Indonesian students, English subject is considered as a foreign language. English is introduced starting from primary to university level of education. The teachers, then, should be able to apply teaching method based on the students' characteristics and their needs in order to gain learning objectives stated by the government. The learning objectives for each level: primary, junior high school and senior high school are also different. The learning objectives of senior high school students include two aspects: (1) the ability to comprehend a text; and (2) the ability to communicate. To communicate is to understand and convey information, thoughts, feelings, as well as to develop science, technology, and culture. Thus, the English subject is pointed to develop listening, speaking, reading and writing skills so that senior high school graduates are able to communicate and discourse in English at certain literacy level. Among these four English language skills integrated in the curriculum, reading skill tends to be the priority. Reading skill has a very important role for those who wish to continue their education to a higher level, or for those who 
wish to succeed in the future [1]. Through reading, students are able to understand and work with the most current information.

Based on my experience and point of view, several problems are still found in daily teaching and learning process. Many students still have unsatisfactory level of reading ability. They sometimes are not able to notice the meaning of a text and lead to difficulties to understand the text properly. As a result, they have problems in answering the questions. The inability of students to answer questions is due to their lack of vocabulary, lack of knowledge and less experience to apply suitable reading strategies. Consequently, when they are given the questions related to the text, the students do it sluggishly and feel confused. The other factors causing the poor reading comprehension of students is lack of interest and motivation to read. Many students say that the reason they read is only because they must read, not because they love to read. Lack of family guidance and encouragementas as well as unavailability of good books that raise the students' interest are also some of significant obstacles. The next factor causing the poor reading comprehension of students is their frequency of reading activity. It is known that the reading skill of a student is determined by the impact of how much (frequency) she/he reads. To improve the the classroom, explain the lesson using the lecturing-method, question and answer, discussion, and end with the assignment. Teaching the same subject for many years quality of reading comprehension, the students should multiply their reading activities. From the side of the teachers, there is a tendency that most teachers still use conventional methods of teaching. That means, each time they are going to teach, teachers enter also means that teachers think they do not need to prepare anything [2]. Such situation generates a decayed learning and teaching process, in addition, the students will become passive.

There are many teaching methods suggested by experts that can be applied by the teachers to improve the students' ability as well as to improve their motivation. One of them is the utilization of information and communication technology (ICT) in education. The presence of computers and the internet has brought innovation in teaching and learning process nowadays. The computers and internet not only can be used as a tool in teaching and learning activities, but also can make the teachers be more creative and innovative, as well as facilitate the teaching and learning activities in the classroom [3]. Research has proven that technology has been utilized in all educational areas like: social studies education, mathematics education, science education, and so on [4]. Most of the educators are enthusiastic about using ICT in their teaching. The explosion of ICT utilization in education generates new teaching methods called web-based teaching. Web-based teaching gives a great number of value. First, through the website, students can obtain the teaching materials related to the learning activities including the virtual discussion; moreover, they also can create a flexible learning environment anytime and anywhere [3]. Second, web-based teaching and learning activity helps students to improve their academic achievement. Third, web-based teaching and learning activity provides a flexible and free learning that is not bound by a fixed study schedule. Furthermore, the use of the web can also increase active participation of students in the learning process that may cause the students become more creative and have critical thinking. Research conducted by Muhammad Anas, et al. in [5], proves that web utilization in teaching and learning 
activities is compatible to support the process of interactive communication among teachers, students, and learning materials as required. In short, Web-based learning offers huge opportunities for learning and access to a vast amount of knowledge and information. This idea is also supported by LuuTrong Tuan in [1] who says that governments, educators and the public often believe that combining English language with information technology skills is important to be successful.

One model of the web-based activities applied in the classroom is WebQuest. The WebQuest teaching model is designed [6]. According to Dodge, WebQuest is an inquiry-oriented activity in which some or all of the information required by students come from sources on the internet. In other words, teaching through WebQuest, some or all of the information that is passed to students comes from online resources. Gokalp, et al. [7], claim that WebQuest has been used in learning institutions in various countries as a model to improve and develop the education process. According to Miralles, et al. [8], through the use of WebQuest the students may obtain a significant amount of new information and make sense out of it. While Kurtulus and Ada [9], mention that using WebQuest enables the students to analyze information in decision making process because it initiate critical thinking.

Motivated by the description above, this work elaborates the development of WebQuest which is called M-WebQuest. In summary, the purpose of this research is to develop M-WebQuest to improve reading comprehension attainment of senior high school students Grade XI in Pekanbaru, Riau - Indonesia. Meanwhile, the developed M-WebQuest makes the following contributions:

- Theoretically, this research is very concerned to support previous idea about advantages of web-based teaching and learning activities. Practically, this research should also provide valuable contribution to principals, teachers, students, and other stakeholders in order to achieve the objectives of learning that have been formulated by the government.

- For teachers, the results of this research will increase teachers' insight and knowledge about web-based teaching instruction and motivate them to be more creative in designing interactive teaching methods.

- The developed M-WebQuest can be one alternative way to improve students' attainment in English reading comprehension. For the principal, the results of this research are expected to provide input to improve facilities and infrastructure for web-based instruction. For students, the results of this research are expected to be an inspiration so that the students can follow any pattern of technology-based teaching/learning applied by the teacher, and for the next researcher, the results of this research can be used as a reference.

The rest of this paper is organized as follow. Section 2 presents theoretical background on M-WebQuest. Section 3 present the proposed method. Section 4 presents obtainde results and following by discussion. Finally, Section 5 concludes this work. 


\section{An Overview of M-WebQuest}

The M-WebQuest is an inquiry-oriented teaching model in which the information that the students work with comes from the constructed web, and the purpose is to improve reading comprehension attainment of senior high school students Grade XI in Pekanbaru, Riau - Indonesia. The M-Webquest teaching model is adapted from WebQuest created firstly by Bernie Dodge from San Diego State University in 1995. Dodge was inspired to create a new model of teaching due to the development of technology in language and had an idea to combine traditional teaching method and the WorldWide Web into the classroom. He named the new model as WebQuest. Dodge defined WebQuests as "an inquiry-oriented activity in which some or all of the information that the learners interact with comes from resources on the internet". In 2008, however, Tom March as a co-creator of WebQuests expanded the definition of WebQuest: A WebQuest is a scaffolded learning structure that uses links to essential resources on the World Wide Web and an authentic task to motivate students" investigation of a central, open ended question, development of individual expertise and participation in a final group process that attempts to transform newly acquired information into a more sophisticated understanding.

In teaching and learning activities, WebQuest basically serves as a framework that can be used by teachers for the guidelines of student-centered learning materials by using the internet. WebQuest is an inquiry-based learning approach that helps students in exploring the given questions. WebQuest provides authentic materials and environment using technology for problem solving, information processing, and collaboration. Moreover, WebQuest provide the students with such activities that may engage them in real life problems. The students are assigned a manageable task that direct them toward achieving learning objectives. Kurtulus and Ada [9], pointed out that there are two forms of WebQuest could be designed: short term or long term. A long term WebQuest is designed and completed in longer periods and carried out over three class periods or more while short term WebQuest is designed and completed in one to three class periods. According to March [10], a good WebQuest prompts the learner to apply higher order thinking skills (analysis, synthesis and evaluation). Therefore, WebQuest can help students to acquire, and transform knowledge using constructivist learning and high-level critical thinking in the classroom. Generally, the critical components of each WebQuest generally contain six parts [11]:

- Introduction: Builds on students' previous knowledge and experience. In this section the teacher provides background information and can explicitly mention specific new concepts or principles to prepare the learner for the lesson. This part should be interesting, motivating, and relevant.

- Task: Parts that provide information or description of what the students should do and what they are expected to create as a final product at the time they complete the activities. As far as possible, the task should be meaningful and fun.

- Resources: Points to information from the WWW used by the students to complete the task. This information needs to be specific and carefully selected by the teacher. 
- Process: Includes detail activities or description, step-by-step instructions or timelines the students should take to accomplish the task.

- Conclusion: Brings closure and summary of what has been done. It can also encourage students to go beyond what they have learned, even reflection and discussion of possible extensions.

- Evaluation: Describes the way in which the students' performance will be evaluated. The teacher needs to prepare fair, clear and consistent standard of evaluation.

Lamb and Teclehaimanot in [12]; Turville in [13] add one more component of WebQuest, it is called Guidance or Learning Advice. The teacher provides as an additional advice presented through description of how information should be organized, guiding questions or directions to follow.

Gallego and García in [14], mentions that the integration of technology and knowledge are two important pillars of nowadays society. The use of technology invades much in education activities. This situation forced the teachers to consider the use of computer and internet as well as other digital tools in their everyday teaching activities. When working with WebQuest, the students may obtain information and then transform the information into authentic learning. Lots of researches have been done to determine the effectiveness of WebQuest in teaching different subjects and disciplines in many parts of the world. The results of the researches show that many experts believe WebQuest can be very useful to help the students in improving their knowledge in various areas of English language skills. Awada and Ghaith in [15] mentions that WebQuest improve writing proficiency of grade eight students in Lebanon. This idea is in line with Hadriana in [16], who says that WebQuest application can improve students' English writing skill as well as to provide the students opportunities to develop knowledge while finishing the given tasks. The students may finish the tasks individually, in pairs or in groups depend on the instruction stated in the WebQuest. Tun-Whei Isabel Chuo in [17], mentions that using WebQuest was effective for enhancing writing performance as well as provide a positive learning experience of junior college students in Taiwan.

WebQuest model is not only effective in teaching writing, but it is also effective to improve students' ability in terms of other language skills. Prapinwong in [18] explores the use of WebQuests in an EFL classroom in Thailand.The result of Prapinwong's study shows that using WebQuest significantly improved students' vocabulary. Luu Trong Tuan in [1] proves that the utilization of WebQuest can promote the teaching of reading. Further, he mentions that he gets positive feedback of the students towards the use of WebQuest. In line with Luu Trong Tuan, Aisha Saeed Al-Shamisi in [19], mentions that there is a significant improvement of her students reading ability when she used WebQuest teaching model. In addition, using WebQuest improved students' skill and facilitate knowledge attainment. Not only effective in teaching language skills, Alias, et al in [20], claim that WebQuest is also effective in facilitating student's learning of physics in high school. Gokalp, et al. in [7], conducted a study to evaluate the effectiveness of using WebQuest to teach mathematics. The results also claim that WebQuest can improve students' performance in mathematics. Moreover, research conducted by Abbitt and Ophus in 
[21], indicates an increased level of students' understanding taught by using WebQuest as compared to when taught with traditional learning instructions of curriculum. In addition, computer studies can also be effectively taught using WebQuest as compared to using traditional IT-integrated instructions or curriculum [22]. WebQuest is also useful to provide a problem-based learning, group work, positive attitudes and interaction of the students [23]. Students felt that WebQuests teaching model enhanced collaboration, language skills, reading and higher order thinking skills [19]. In addition, the students agree with the importance and usefulness of using the WebQuest in teaching EFL [15]. WebQuest is also perceived to be a quite useful to support a problem-based learning, group work as well as interaction of the students. A WebQuest teaching model assisted to create a learning environment, fostered critical thinking skills, creativity and had a motivational effect on learners. The habit of analyzing information from WebQuest ensures high level of students' critical thinking [24]. Maria \& Marta in [25] claims that the use of WebQuest motivates the students towards the teaching and learning of the English subject, improves their digital competence as well as their cultural competence. However, a research conducted by Yang in [26], revealed that a failure to correctly and carefully implement WebQuests may lead to poor academic performance. At last, WebQuest teaching model may cause a greater interest of the students when engaged in authentic tasks and with authentic material, the importance of mutual help, a greater feeling of learning and the increase in knowledge. The students like the WebQuest teaching model because it also enable them to have a discussion in the class and sharing responsibility for assignment fulfillment. However, a lack of computers connected to internet and inadequate internet connection decreased students 'inspiration. Some of students also felt uncomfortable working collaboratively on one computer and would not prefer to employ it in further classes.

Inspired by lots advantages of WebQuest, it is interesting to create new teaching model that can be applied for senior high school students in Pekanbaru, Riau Indonesia. The new teaching model is called M-WebQuest.

\section{M-WebQuest Development Methodology}

In this research, the development of M-WebQuest modified ADDIE design model. ADDIE model is interesting because each phase in the ADDIE model has output and the output is being input to the next phase. The ADDIE model consists of five phases: analysis, design, development, implementation and evaluation.

- Analysis phase:. This phase started from the analysis of the curriculum and syllabus released by the Ministry of Education of Indonesian Republic, in order to scope the teaching materials should be included. The next things to analyze are the students' characteristics, and the availability / qualification of facilities and learning environment.

- Design phase: This phase is implemented after the analysis process is completed. At this phase teaching materials were prepared and learning activities in MWebQuest were planned, so that at the end a story board is created. The learning 
activities presented in M-WebQuest were tailored to the principles of WebQuest development [27].

- Development phase: At this phase a flowchart to facilitate organizing the material into WebQuest form was built. This flowchart starts from the home page, which contains the main M-WebQuest menu screen. Then followed by the next pages. Once the materials and flowcharts have been completed, the M-WebQuest is ready to be published on the internet.

- Implementation phase: Once the M-WebQuest is published on the internet, its qualifications need to be tested to identify unnoticed problems during the design and development phase that may exist.This phase is implemented using a group of students who meet the criteria set.

- Evaluation phase: Was carried out to ensure the feasibility of M-WebQuest products that were built. The evaluation is done in terms of technical and content, impacts for students and teachers, interface screen, and texts.

Assessment of M-WebQuest feasibility involved 3 IT experts, 10 English teachers, and 30 students. The instrument used for the feasibility was a questionnaire modified from [28]. Given responses are compiled according to Likert scale: very good, good, medium, bad and very bad. Feedback, input and suggestions for the accuracy, validity, and feasibility of the product were also asked from the experts, English teachers and students. Revision on the M-WebQuest conducted based on the analysis of the questionnaire.

\section{$4 \quad$ Results and Discussions}

\subsection{M-WebQuest development}

As mentioned before, the development of M-WebQuest used ADDIE design model. During analysis phase it was found out that:

- According to the regulation released by the Ministry of Education of Indonesian Republic, the learning materials for senior high school students Grade XI are related to Report, Narrative, Analytical Exposition, and Hortatory Exposition Text. So, the created M-WebQuest refers to these texts only

- The students as the user of the M-WebQuest later on, have been familiar of how to follow the activities of English teaching and learning using web-based instruction;

- Most schools in Pekanbaru, Riau - Indonesia have already provided free public internet access via Wi-Fi network. This means that anyone, including the teachers and the students, who are in the Wi-Fi area of a school can use the internet. Besides, teachers and many students are used to bring smartphones to school, so that they can use it as an alternative if the school Wi-Fi has some problems. After reviewing the curriculum, users' characteristics and the availability of the facility and infrastructure, the next step is to prepare the materials and design the learning activities in M-WebQuest. 
At the design phase, the materials and learning activities were prepared, then the flowchart/workflow was created to support the organization of the materials set into the form of M-WebQuest. The first screen of the M-WebQuest is the home page. In the second screen, there is a little bit 'information about the author' as well as 'warning' and 'direction'. The next part is the main menu of the M-WebQuest Introduction, Task, Process, Resources, Evaluation, Conclusion and Teacher's for each kind of text. Once the materials and the flowchart are completed, the MWebQuest is ready to publish on the internet. The following pictures display examples of M-WebQuest sites.

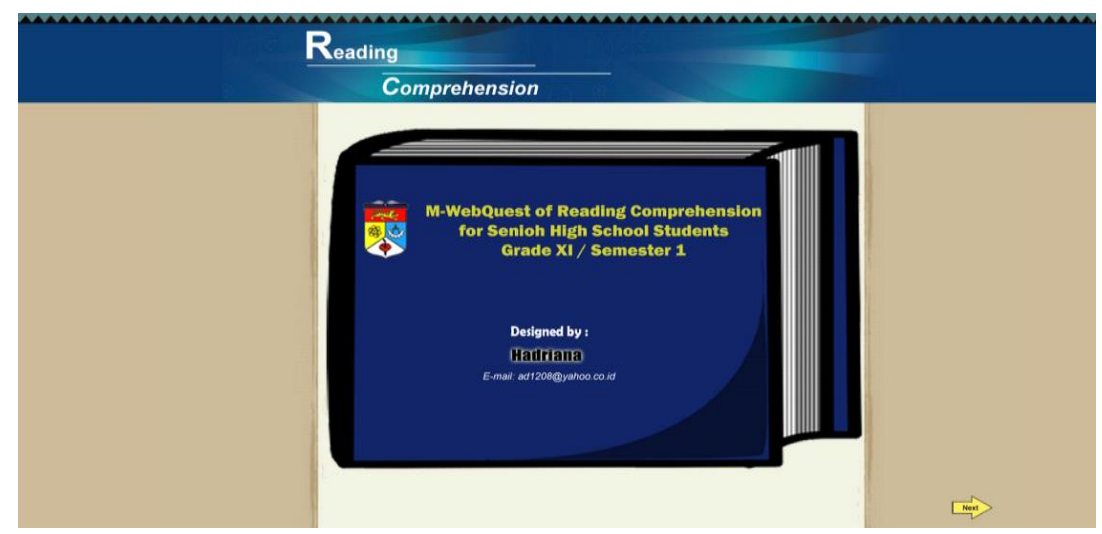

Fig. 1. Home Page of the M-WebQuest

Figure 1 is the Home Page of the M-WebQuest. Here, the name of the MWebQuest and the identity of the designer are mentioned.

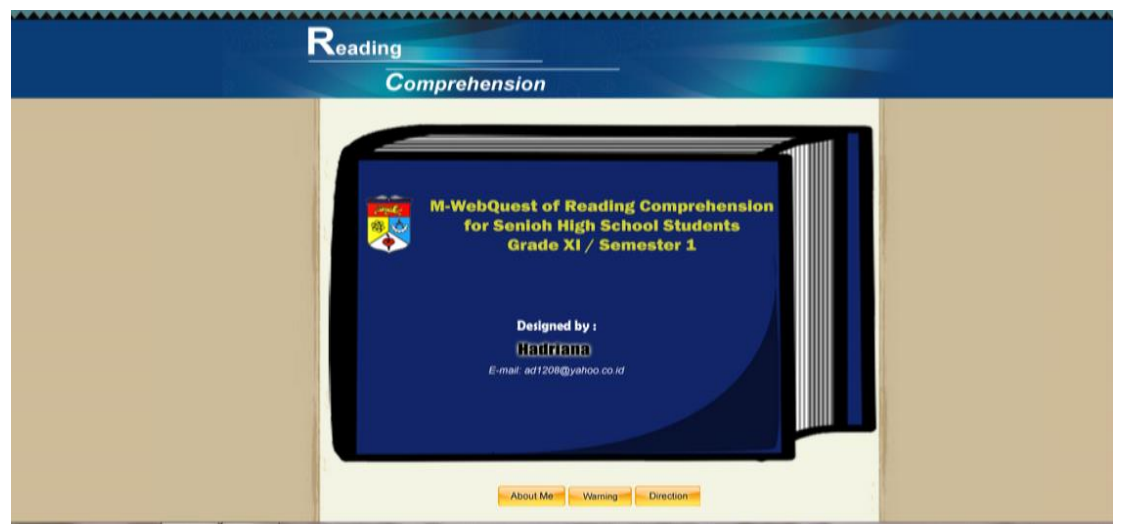

Fig. 2. The second Screen of M-WebQuest

Figure 2 above is the second screen of the M-WebQuest. In this part, 'About Me', 'Warning' and 'Direction' are given. It's necessary for the users - the teachers and the 
students - to read these aspects first before stating using the M-Quesst. Click the provided bottom before reading.

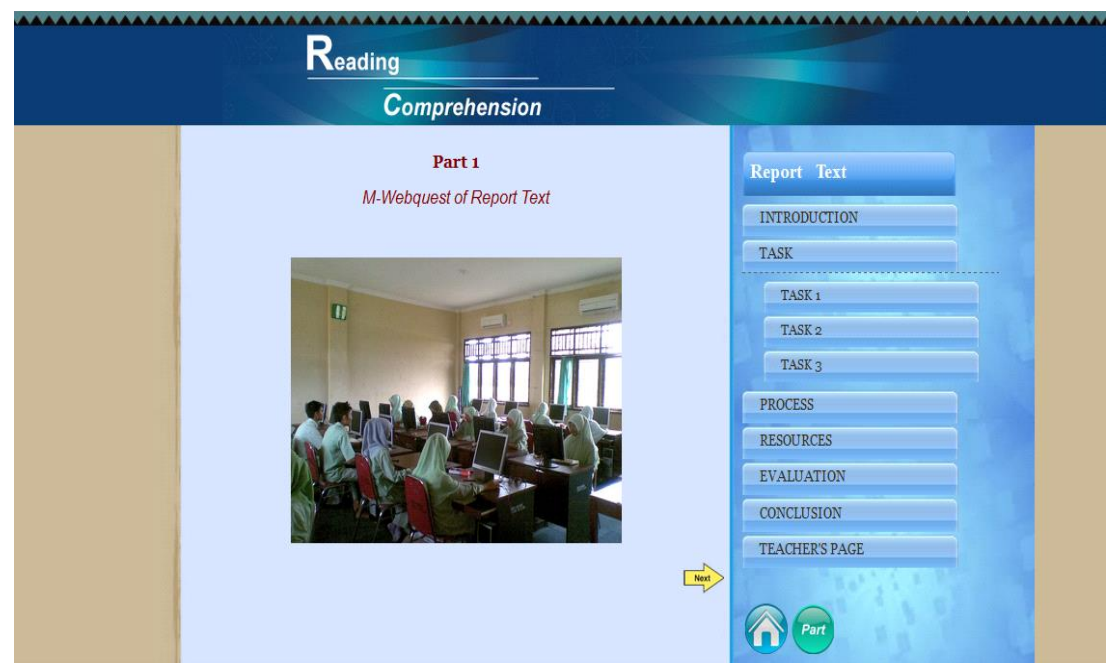

Fig. 3. M-WebQuest of Report Text

Figure 3 is the first part of the M-WebQuest that is called M-WebQuest of Report Text. When opening this page, the students are start studying. First they click 'Introduction' bottom. At this section they can read information about Report Text that may builds their knowledge and lead them to know the concept of Report Text. The next bottom is 'Task', that provide information or description of the tasks that the students should complete. To know the procedure of doing the tasks, they must click 'Process' bottom that gives detail activities or description of step-by-step instructions or timelines the students should take to accomplish the tasks. When the students click 'Resources' bottom, they will get lots of information that they may use to complete the tasks as well as more explanation about aspects related to Report Text. If the students want to get summary of what has been done or even reflection, they may click 'Conclusion' bottom. Finally, when the students click 'Evaluation' bottom, there will be a description about the way in which the students' performance will be evaluated. The rubric of the evaluation is also provided here. 'Teachers' page' is special part for teachers. The students cannot access this part. In this part, formative and summative test together with the answer keys are provided. 


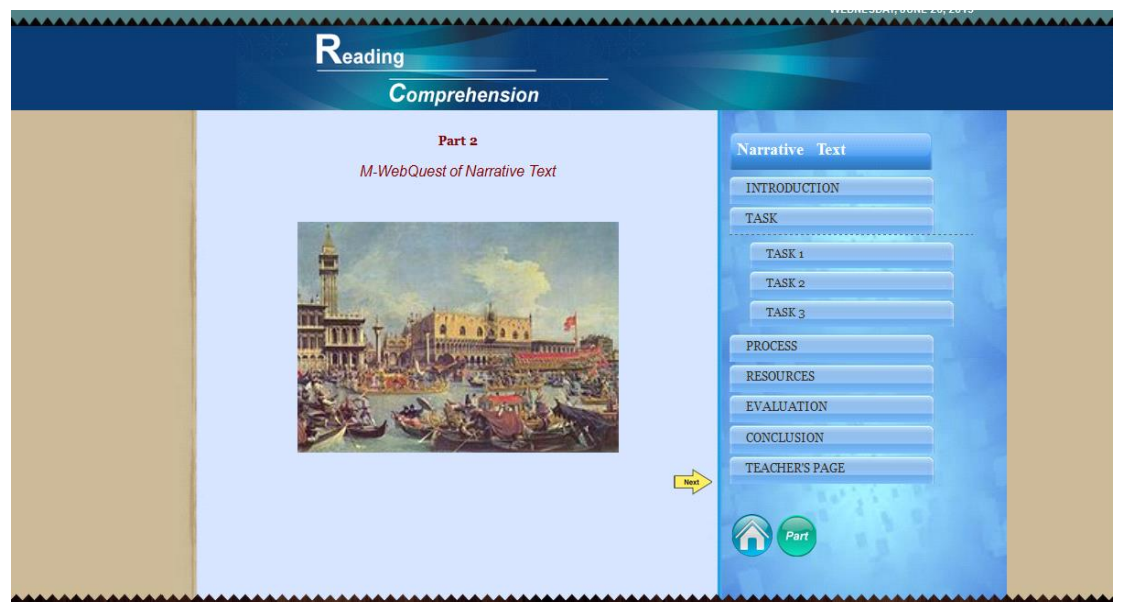

Fig. 4. An example of M-WebQuest sites

Figure 4 is the second part of the M-WebQuest, which is called M-WebQuest of Narrative Text. The way the students studying this kind of text is similar to the way of studying Report Text. The third and the fourt parts are M-WebQuest of Analytical Exposition Text, and M-WebQuest of Hortatory Exposition Text. These four MWebQuest includes all the teaching materials for the whole semester.

\subsection{Evaluation of M-WebQuest development}

Once the M-WebQuest is published on the internet, it is ready to be implemented in the teaching and learning activities of Reading English. However, before the MWebQuest is used, the actual evaluation should be conducted to ensure the feasibility of using M-WebQuest in teaching and learning activities. The evaluation was conducted by experts, English teachers and students. Feedback, input and suggestions on the accuracy, truth, and feasibility of the products were also asked from them. Here are detailed findings on M-WebQuest development evaluation from experts, teachers and students.

Evaluation from experts: The evaluation was conducted by 3 experts, namely experts of ICT, TEFL, and Linguistics. The descriptive analysis of every aspect evaluated in the M-WebQuest evaluation instruments is given in Table 1 as follows. 
Table 1. Evaluation on M-WebQuest in Terms of Technical

\begin{tabular}{|c|c|c|c|c|c|c|}
\hline \multirow[t]{2}{*}{ No } & \multirow[t]{2}{*}{ Aspects Evaluated } & \multicolumn{5}{|c|}{ Scales } \\
\hline & & $S A$ & $A$ & $N A D$ & DA & $S D A$ \\
\hline & \multicolumn{6}{|l|}{ Navigation } \\
\hline 1 & Clear instructions for each step & 2 experts $(66.7 \%)$ & 1 expert $(33.3 \%)$ & $(0 \%)$ & $(0 \%)$ & $(0 \%)$ \\
\hline 2 & Clear links among the screen & 1 expert $(33.3 \%)$ & 2 experts $(66.7 \%)$ & $(0 \%)$ & $(0 \%)$ & $(0 \%)$ \\
\hline \multirow[t]{2}{*}{3} & Easy to learn the program & 1 expert $(33.3 \%)$ & 2 experts $(66.7 \%)$ & $(0 \%)$ & $(0 \%)$ & $(0 \%)$ \\
\hline & Design: & & & & & \\
\hline 1 & $\begin{array}{l}\text { Easy to read the characters on the } \\
\text { screen }\end{array}$ & 1 expert $(33.3 \%)$ & 2 experts $(66.7 \%)$ & $(0 \%)$ & $(0 \%)$ & $(0 \%)$ \\
\hline 2 & $\begin{array}{l}\text { Balanced composition of letters, col- } \\
\text { ors, and shapes }\end{array}$ & 1 expert $(33.3 \%)$ & 2 experts $(66.7 \%)$ & $(0 \%)$ & $(0 \%)$ & $(0 \%)$ \\
\hline 3 & Use of appropriate picture & 1 expert $(33.3 \%)$ & 1 expert $(33.3 \%)$ & $\begin{array}{l}1 \text { expert } \\
(33.3 \%)\end{array}$ & $(0 \%)$ & $(0 \%)$ \\
\hline 4 & Free from biased image / color & & 2 experts $(66.7 \%)$ & $\begin{array}{l}1 \text { expert } \\
(33.3 \%)\end{array}$ & $(0 \%)$ & $(0 \%)$ \\
\hline 5 & In general, the visual is interesting & 2 experts $(66.7 \%)$ & 1 expert $(33.3 \%)$ & $(0 \%)$ & $(0 \%)$ & $(0 \%)$ \\
\hline
\end{tabular}

$\mathrm{SA}=$ Strongly Agree; $\mathrm{A}=$ Agree NAD = Neither Agree nor Disagree; $\mathrm{DA}=$ Disagree SDA = Strongly Disagree

Table 1 above indicates that the experts agree about the feasibility of M-WebQuest in terms of navigation and design. The experts' evaluation in terms of content can be seen in the following Table 2.

Table 2. Evaluation on M-WebQuest in Terms of Content

\begin{tabular}{|c|l|c|c|c|c|c|}
\hline \multirow{2}{*}{ No } & \multicolumn{2}{|c|}{ Aspects Evaluated } & \multicolumn{4}{c|}{ Scales } \\
\cline { 3 - 6 } & & $\boldsymbol{S A}$ & $\boldsymbol{A}$ & $\boldsymbol{N A D}$ & $\boldsymbol{D A}$ & $\mathbf{S D A}$ \\
\hline 1 & In accordance with the curriculum. & 1 expert $(33.3 \%)$ & 2 experts $(66.7 \%)$ & $(0 \%)$ & $(0 \%)$ & \\
\hline 2 & Accurate and up-to-date. & 2 experts $(66.7 \%)$ & 1 expert $(33.3 \%)$ & $(0 \%)$ & $(0 \%)$ & \\
\hline 3 & Logical relationships between topics. & 1 expert $(33.3 \%)$ & 2 experts $(66.7 \%)$ & $(0 \%)$ & $(0 \%)$ & \\
\hline 4 & Appropriate language usage. & $(0 \%)$ & 3 experts $(100 \%)$ & $(0 \%)$ & $(0 \%)$ & \\
\hline 5 & Potential for activity in class. & 1 expert $(33.3 \%)$ & 2 experts $(66.7 \%)$ & $(0 \%)$ & $(0 \%)$ & $(0 \%)$ \\
\hline
\end{tabular}

$\mathrm{SA}=$ Strongly Agree; $\mathrm{A}=$ Agree $; \mathrm{NAD}=$ Neither Agree nor Disagree; $\mathrm{DA}=$ Disagree SDA $=$ Strongly Disagree

Table 2 above indicates that the experts agree about the feasibility of M-WebQuest in terms of content. The next aspect evaluated by the experts is related to the material unit of the M-WebQuest: content, introduction, task, process, resources, and the evaluation of M-WebQuest created.This is the 'core' of the M-WebQuest because this part is related to subject matter that must be mastered by the students as well as the way how to gain understanding and knowledge of that subject matter. The results of the evaluation can be seen in the following Table 3. 
Table 3. Evaluation on M-WebQuest in Terms of Material Unit

\begin{tabular}{|c|c|c|c|c|c|c|}
\hline \multirow[t]{2}{*}{ No } & \multirow[t]{2}{*}{ Aspects Evaluated } & \multicolumn{5}{|c|}{ Scales } \\
\hline & & $S A$ & $A$ & $N A D$ & $D A$ & $S D A$ \\
\hline & \multicolumn{6}{|l|}{ Introduction } \\
\hline 1 & $\begin{array}{l}\text { The introductory section arises students' motivation } \\
\text { to learn }\end{array}$ & $\begin{array}{l}2 \text { experts } \\
(66.7 \%)\end{array}$ & $\begin{array}{l}1 \text { expert } \\
(33.3 \%)\end{array}$ & $(0 \%)$ & $(0 \%)$ & $(0 \%)$ \\
\hline \multirow[t]{2}{*}{2} & Provide initial knowledge about what to learn & $\begin{array}{l}1 \text { expert } \\
(33.3 \%)\end{array}$ & $\begin{array}{l}2 \text { experts } \\
(66.7 \%)\end{array}$ & $(0 \%)$ & $(0 \%)$ & $(0 \%)$ \\
\hline & \multicolumn{6}{|l|}{ Tasks } \\
\hline 1 & The 'tasks' are relevant to the curriculum & $2(66.7 \%)$ & $\begin{array}{l}1 \text { expert } \\
(33.3 \%)\end{array}$ & $(0 \%)$ & $(0 \%)$ & $(0 \%)$ \\
\hline 2 & $\begin{array}{l}\text { Provide clear understanding about what to achieve } \\
\text { at the end of learning activities }\end{array}$ & $\begin{array}{l}1 \text { expert } \\
(33.3 \%)\end{array}$ & $\begin{array}{l}2 \text { experts } \\
(66.7 \%)\end{array}$ & $(0 \%)$ & $(0 \%)$ & $(0 \%)$ \\
\hline 3 & $\begin{array}{l}\text { Level of exercises difficulties is in accordance with } \\
\text { students' cognitive level }\end{array}$ & $\begin{array}{l}1 \text { expert } \\
(33.3 \%)\end{array}$ & $\begin{array}{l}1 \text { expert } \\
(33.3 \%)\end{array}$ & $\begin{array}{l}1 \text { expert } \\
(33.3 \%)\end{array}$ & $(0 \%)$ & $(0 \%)$ \\
\hline \multirow[t]{2}{*}{4} & Supports the achievement of higher-level thinking & $\begin{array}{l}1 \text { expert } \\
(33.3 \%)\end{array}$ & $\begin{array}{c}2 \text { experts } \\
(66.7 \%)\end{array}$ & $(0 \%)$ & $(0 \%)$ & $(0 \%)$ \\
\hline & \multicolumn{6}{|l|}{ Process } \\
\hline 1 & Steps of what the students should do are clear & $2(66.7 \%)$ & $\begin{array}{l}1 \text { expert } \\
(33.3 \%)\end{array}$ & $(0 \%)$ & $(0 \%)$ & $(0 \%)$ \\
\hline 2 & $\begin{array}{l}\text { Activities are clearly designed to bring students' } \\
\text { basic knowledge to higher thinking }\end{array}$ & $\begin{array}{l}1 \text { expert } \\
(33.3 \%)\end{array}$ & $\begin{array}{c}2 \text { experts } \\
(66.7 \%)\end{array}$ & $(0 \%)$ & $(0 \%)$ & $(0 \%)$ \\
\hline \multirow[t]{2}{*}{3} & Individual roles in the group are clearly stated & $\begin{array}{l}1 \text { expert } \\
(33.3 \%)\end{array}$ & $\begin{array}{l}1 \text { expert } \\
(33.3 \%)\end{array}$ & $\begin{array}{l}1 \text { expert } \\
(33.3 \%)\end{array}$ & $(0 \%)$ & $(0 \%)$ \\
\hline & \multicolumn{6}{|l|}{ Resources } \\
\hline 1 & $\begin{array}{l}\text { Resources used are relevant to the theme of the } \\
\text { lesson }\end{array}$ & $\begin{array}{l}1 \text { expert } \\
(33.3 \%)\end{array}$ & $\begin{array}{c}2 \text { experts } \\
(66.7 \%)\end{array}$ & $(0 \%)$ & $(0 \%)$ & $(0 \%)$ \\
\hline \multirow[t]{2}{*}{2} & Quantity and quality of resources are sufficient & $\begin{array}{l}1 \text { expert } \\
(33.3 \%)\end{array}$ & $\begin{array}{c}2 \text { experts } \\
(66.7 \%)\end{array}$ & $(0 \%)$ & $(0 \%)$ & $(0 \%)$ \\
\hline & \multicolumn{6}{|l|}{ Evaluation } \\
\hline 1 & Criteria of evaluation are clear & $\begin{array}{l}1 \text { expert } \\
(33.3 \%)\end{array}$ & $\begin{array}{l}2 \text { experts } \\
(66.7 \%)\end{array}$ & $(0 \%)$ & $(0 \%)$ & $(0 \%)$ \\
\hline 2 & $\begin{array}{l}\text { The evaluation section covers quantitative and } \\
\text { qualitative descriptors. }\end{array}$ & $\begin{array}{l}2 \text { expert } \\
(66.7 \%)\end{array}$ & $\begin{array}{l}1 \text { expert } \\
(33.3 \%)\end{array}$ & $(0 \%)$ & $(0 \%)$ & $(0 \%)$ \\
\hline 3 & $\begin{array}{l}\text { The evaluation instrument clearly measures what the } \\
\text { student should achieve }\end{array}$ & 1 expert & $\begin{array}{c}2 \text { experts } \\
(66.7 \%)\end{array}$ & $(0 \%)$ & $(0 \%)$ & $(0 \%)$ \\
\hline \multirow[t]{2}{*}{4} & $\begin{array}{l}\text { Evaluation criteria are relevant to the purpose of } \\
\text { learning and curriculum }\end{array}$ & $\begin{array}{l}1 \text { expert } \\
(33.3 \%)\end{array}$ & $\begin{array}{c}2 \text { experts } \\
(66.7 \%)\end{array}$ & $(0 \%)$ & $(0 \%)$ & $(0 \%)$ \\
\hline & \multicolumn{6}{|l|}{ Conclusion } \\
\hline 1 & $\begin{array}{l}\text { Conclusions remind students of what has been } \\
\text { learned }\end{array}$ & $\begin{array}{l}2 \text { experts } \\
(66.7 \%)\end{array}$ & $\begin{array}{l}1 \text { expert } \\
(33.3 \%)\end{array}$ & $(0 \%)$ & $(0 \%)$ & $(0 \%)$ \\
\hline 2 & The conclusions provided allow students to reflect & 1 expert & $\begin{array}{l}2 \text { experts } \\
(66.7 \%) \\
\end{array}$ & $(0 \%)$ & $(0 \%)$ & $(0 \%)$ \\
\hline
\end{tabular}

$\mathrm{SA}=$ Strongly Agree $; \mathrm{A}=$ Agree $\mathrm{NAD}=$ Neither Agree nor Disagree $\mathrm{DA}=$ Disagree SDA $=$ Strongly Disagree

Based on Table 3 above, it can be seen that the experts agree about the feasibility of material unit of the M-WebQuest: content, introduction, task, process, resources, and the evaluation. The next aspects evaluated by experts are the impacts of using MWebQuest to the students and the teachers. Look at the following Table 4. 
Table 4. Impact of Using M-WebQuest

\begin{tabular}{|c|c|c|c|c|c|c|}
\hline \multirow[t]{2}{*}{ No } & \multirow[t]{2}{*}{ Aspects Evaluated } & \multicolumn{5}{|c|}{ Scales } \\
\hline & & $S A$ & $A$ & $N A D$ & $D A$ & $S D A$ \\
\hline & \multicolumn{6}{|l|}{ Impact on Students } \\
\hline 1 & Improve students' motivation & 2 experts $(66.7 \%)$ & $\begin{array}{l}1 \text { expert } \\
(33.3 \%)\end{array}$ & $(0 \%)$ & $(0 \%)$ & $(0 \%)$ \\
\hline 2 & $\begin{array}{l}\text { Increase students' confidence in using com- } \\
\text { puters and the internet }\end{array}$ & 1 expert $(33.3 \%)$ & $2(66.7 \%)$ & $(0 \%)$ & $(0 \%)$ & $(0 \%)$ \\
\hline \multirow[t]{2}{*}{3} & $\begin{array}{l}\text { Stimulate students to think and interact with } \\
\text { teachers and other students }\end{array}$ & 2 experts $(66.7 \%)$ & $\begin{array}{l}1 \text { expert } \\
(33.3 \%)\end{array}$ & $(0 \%)$ & $(0 \%)$ & $(0 \%)$ \\
\hline & \multicolumn{6}{|l|}{ Impact on Teachers } \\
\hline 1 & $\begin{array}{l}\text { It only takes a little time to learn the use of } \\
\text { M-WebQuest effectively }\end{array}$ & 1 expert $(33.3 \%)$ & $\begin{array}{l}2 \text { experts } \\
(66.7 \%)\end{array}$ & $(0 \%)$ & $(0 \%)$ & $(0 \%)$ \\
\hline 2 & $\begin{array}{l}\text { Improve the quality of teaching and learn- } \\
\text { ing process }\end{array}$ & $\mathbf{1}$ expert $(33.3 \%)$ & $\begin{array}{l}2 \text { experts } \\
(66.7 \%)\end{array}$ & $(0 \%)$ & $(0 \%)$ & $(0 \%)$ \\
\hline
\end{tabular}

$\mathrm{SA}=$ Strongly Agree; $\mathrm{A}=$ Agree; $\mathrm{NAD}=$ Neither Agree nor Disagree; $\mathrm{DA}=$ Disagree; $\mathrm{SDA}=$ Strongly Disagree

According to Table 4 above, all experts agree that M-WebQuest can give positive impacts to the students as well as the teachers. Overall, it can be concluded that the experts agree on the validation of M-WebQuest product development from the technical, content, material unit and its impacts to the students and the teachers. There is no suggestion given by experts associated with the improvement of M-WebQuest.

Evaluation from teachers: The evaluation from teachers involved 10 English teachers. These teachers evaluated the feasibility of the M-WebQuest in terms of technical and in terms of content. The descriptive analysis of every aspect evaluated in the M-WebQuest evaluation can be seen in Tables 5 and 6 .

Table 5. Teachers' Evaluation in Terms of Technical

\begin{tabular}{|c|c|c|c|c|c|c|}
\hline \multirow[t]{2}{*}{ No } & \multirow[t]{2}{*}{ Aspects Evaluated } & \multicolumn{5}{|c|}{ Scales } \\
\hline & & $S A$ & $\boldsymbol{A}$ & $N A D$ & $D A$ & $S D A$ \\
\hline & \multicolumn{6}{|l|}{ Interface Screen } \\
\hline 1 & The appearance is interesting & $\begin{array}{c}4 \text { teachers } \\
(40 \%)\end{array}$ & $\begin{array}{c}5 \text { teachers } \\
(50 \%)\end{array}$ & $\begin{array}{c}1 \text { teacher } \\
(10 \%)\end{array}$ & $(0 \%)$ & $(0 \%)$ \\
\hline 2 & The colors used are appropriate & $\begin{array}{c}3 \text { teachers } \\
(30 \%)\end{array}$ & $\begin{array}{c}4 \text { teachers } \\
(40 \%)\end{array}$ & $\begin{array}{c}3 \text { teachers } \\
(30 \%)\end{array}$ & $(0 \%)$ & $(0 \%)$ \\
\hline 3 & The size is suitable and easy to read & $\begin{array}{c}6 \text { teachers } \\
(60 \%)\end{array}$ & $\begin{array}{c}4 \text { teachers } \\
(40 \%)\end{array}$ & $(0 \%)$ & $(0 \%)$ & $(0 \%)$ \\
\hline 4 & Easy to learn anywhere & $\begin{array}{c}5 \text { teachers } \\
(50 \%)\end{array}$ & $\begin{array}{c}5 \text { teachers } \\
(50 \%)\end{array}$ & $(0 \%)$ & $(0 \%)$ & $(0 \%)$ \\
\hline \multirow[t]{2}{*}{5} & $\begin{array}{l}\text { Availability of instructions provides con- } \\
\text { venience in learning }\end{array}$ & $\begin{array}{l}1 \text { teacher } \\
(10 \%)\end{array}$ & $\begin{array}{c}7 \text { teachers } \\
(70 \%)\end{array}$ & \begin{tabular}{|c|}
2 teachers \\
$(20 \%)$
\end{tabular} & $(0 \%)$ & $(0 \%)$ \\
\hline & \multicolumn{6}{|l|}{ Text } \\
\hline 1 & The text size used is clear and easy to read & $\begin{array}{l}7 \text { teachers } \\
(70 \%)\end{array}$ & $\begin{array}{c}3 \text { teachers } \\
(30 \%)\end{array}$ & $(0 \%)$ & $(0 \%)$ & $(0 \%)$ \\
\hline 2 & Integration of text is suitable & $\begin{array}{c}4 \text { teachers } \\
(40 \%)\end{array}$ & $\begin{array}{c}6 \text { teachers } \\
(60 \%)\end{array}$ & $(0 \%)$ & $(0 \%)$ & $(0 \%)$ \\
\hline 3 & Appearance of text can attract attention & $\begin{array}{c}3 \text { teachers } \\
(30 \%)\end{array}$ & $\begin{array}{c}4 \text { teachers } \\
(40 \%)\end{array}$ & $\begin{array}{c}3 \text { teachers } \\
(30 \%)\end{array}$ & $(0 \%)$ & $(0 \%)$ \\
\hline
\end{tabular}




\begin{tabular}{|c|l|c|c|c|c|c|}
\hline 4 & $\begin{array}{l}\text { Combination of text, pictures and colors } \\
\text { can help students to understand the subject } \\
\text { matter more easily }\end{array}$ & $\begin{array}{c}1 \text { teacher } \\
(10 \%)\end{array}$ & $\begin{array}{c}4 \text { teachers } \\
(40 \%)\end{array}$ & $\begin{array}{c}5 \text { teachers } \\
(50 \%)\end{array}$ & $(0 \%)$ & $(0 \%)$ \\
\hline
\end{tabular}

$\mathrm{SA}=$ Strongly Agree; $\mathrm{A}=$ Agree NAD = Neither Agree nor Disagree $; \mathrm{DA}=$ Disagree SDA $=$ Strongly Disagree

According to Table 5, the teachers agree on the feasibility of M-WebQuest developed in terms of technical - the interface screen and text created. The teachers' evaluation on the feasibility of the M-WebQuest in terms of content can be seen in the following Table 6 .

Table 6. Teachers' Evaluation in Terms of Content

\begin{tabular}{|c|c|c|c|c|c|c|}
\hline \multirow[t]{2}{*}{ No } & \multirow[t]{2}{*}{ Aspects Evaluated } & \multicolumn{5}{|c|}{ Scales } \\
\hline & & $S A$ & $A$ & $N A D$ & $D A$ & $S D A$ \\
\hline 1 & Content is easy to follow & $\begin{array}{c}2 \text { teachers } \\
(20 \%)\end{array}$ & $\begin{array}{c}4 \text { teachers } \\
(40 \%)\end{array}$ & $\begin{array}{c}4 \text { teachers } \\
(40 \%)\end{array}$ & $(0 \%)$ & $(0 \%)$ \\
\hline 2 & $\begin{array}{l}\text { The content helps students understand the needs } \\
\text { of using M-WebQuest. }\end{array}$ & $\begin{array}{c}4 \text { teachers } \\
(40 \%)\end{array}$ & \begin{tabular}{|c|}
$\begin{array}{c}3 \text { teachers } \\
(30 \%)\end{array}$ \\
\end{tabular} & $\begin{array}{c}3 \text { teachers } \\
(30 \%)\end{array}$ & $(0 \%)$ & $(0 \%)$ \\
\hline 3 & $\begin{array}{l}\text { Content helps students identify the component of } \\
\text { M-WebQuest menus involved to complete the } \\
\text { task }\end{array}$ & $\begin{array}{c}6 \text { teachers } \\
(60 \%)\end{array}$ & $\begin{array}{c}4 \text { teachers } \\
(40 \%)\end{array}$ & $(0 \%)$ & $(0 \%)$ & $(0 \%)$ \\
\hline 4 & $\begin{array}{l}\text { The content helps students draw concepts of } \\
\text { subject matter. }\end{array}$ & $\begin{array}{c}4 \text { teachers } \\
(40 \%)\end{array}$ & $\begin{array}{c}4 \text { teachers } \\
(40 \%)\end{array}$ & $\begin{array}{c}2 \text { teachers } \\
(20 \%)\end{array}$ & $(0 \%)$ & $(0 \%)$ \\
\hline 5 & $\begin{array}{l}\text { Content is in line with the knowledge that the } \\
\text { student needs to achieve. }\end{array}$ & $\begin{array}{c}5 \text { teachers } \\
(50 \%)\end{array}$ & \begin{tabular}{|c|}
5 teachers \\
$(50 \%)$
\end{tabular} & $(0 \%)$ & $(0 \%)$ & $(0 \%)$ \\
\hline 6 & $\begin{array}{l}\text { Content is in line with the skills that the student } \\
\text { needs to achieve. }\end{array}$ & $\begin{array}{c}7 \text { teachers } \\
(70 \%)\end{array}$ & \begin{tabular}{|c|}
$\begin{array}{c}4 \text { teachers } \\
(40 \%)\end{array}$ \\
\end{tabular} & $\begin{array}{c}2 \text { teachers } \\
(20 \%)\end{array}$ & $(0 \%)$ & $(0 \%)$ \\
\hline 7 & $\begin{array}{l}\text { The content is organized from easy into difficult } \\
\text { subject matter. }\end{array}$ & $\begin{array}{c}6 \text { teachers } \\
(60 \%)\end{array}$ & $\begin{array}{c}3 \text { teachers } \\
(30 \%)\end{array}$ & $\begin{array}{c}1 \text { teacher } \\
(10 \%)\end{array}$ & $(0 \%)$ & $(0 \%)$ \\
\hline 8 & Examples provided are sufficient. & 5 teachers & 5 teachers & $(0 \%)$ & $(0 \%)$ & $(0 \%)$ \\
\hline 9 & The explanation provided is complete. & $\begin{array}{c}5 \text { teachers } \\
(50 \%)\end{array}$ & \begin{tabular}{|c|}
$\begin{array}{c}3 \text { teachers } \\
(30 \%)\end{array}$ \\
\end{tabular} & $\begin{array}{c}2 \text { teachers } \\
(20 \%)\end{array}$ & $(0 \%)$ & $(0 \%)$ \\
\hline 10 & $\begin{array}{l}\text { Activities provided are in line with the objectives } \\
\text { of learning. }\end{array}$ & $\begin{array}{c}3 \text { teachers } \\
(30 \%)\end{array}$ & $\begin{array}{c}3 \text { teachers } \\
(30 \%)\end{array}$ & $\begin{array}{c}4 \text { teachers } \\
(40 \%)\end{array}$ & $(0 \%)$ & $(0 \%)$ \\
\hline 20 & $\begin{array}{l}\text { Exercises given are in line with the objectives of } \\
\text { learning. }\end{array}$ & $\begin{array}{c}4 \text { teachers } \\
(40 \%)\end{array}$ & \begin{tabular}{|c|}
$\begin{array}{c}4 \text { teachers } \\
(40 \%)\end{array}$ \\
\end{tabular} & $\begin{array}{c}2 \text { teachers } \\
(20 \%)\end{array}$ & $(0 \%)$ & $(0 \%)$ \\
\hline 21 & $\begin{array}{l}\text { Encourages students to carry out sustainable } \\
\text { activities. }\end{array}$ & $\begin{array}{c}4 \text { teachers } \\
(40 \%)\end{array}$ & $\begin{array}{c}5 \text { teachers } \\
(50 \%)\end{array}$ & $\begin{array}{c}1 \text { teacher } \\
(10 \%)\end{array}$ & $(0 \%)$ & $(0 \%)$ \\
\hline 22 & Provide appropriate steps. & $\begin{array}{c}5 \text { teachers } \\
(50 \%)\end{array}$ & $\begin{array}{c}4 \text { teachers } \\
(40 \%)\end{array}$ & $\begin{array}{c}1 \text { teacher } \\
(10 \%)\end{array}$ & $(0 \%)$ & $(0 \%)$ \\
\hline 23 & Steps provided are effective. & \begin{tabular}{|c|}
5 teachers \\
$(50 \%)$
\end{tabular} & \begin{tabular}{|c|}
3 teachers \\
$(30 \%)$
\end{tabular} & $\begin{array}{c}2 \text { teachers } \\
(20 \%)\end{array}$ & $(0 \%)$ & $(0 \%)$ \\
\hline 24 & $\begin{array}{l}\text { Assessment provided is tailored to the learning } \\
\text { objective. }\end{array}$ & $\begin{array}{c}5 \text { teachers } \\
(50 \%)\end{array}$ & $\begin{array}{c}5 \text { teachers } \\
(50 \%)\end{array}$ & $(0 \%)$ & $(0 \%)$ & $(0 \%)$ \\
\hline 25 & The exercises available are appropriate. & $\begin{array}{c}4 \text { teachers } \\
(40 \%)\end{array}$ & $\begin{array}{c}4 \text { teachers } \\
(40 \%)\end{array}$ & $\begin{array}{c}2 \text { teachers } \\
(20 \%)\end{array}$ & $(0 \%)$ & $(0 \%)$ \\
\hline
\end{tabular}

$\mathrm{SA}=$ Strongly Agree; $\mathrm{A}=$ Agree NAD = Neither Agree nor Disagree; $\mathrm{DA}=$ Disagree SDA $=$ Strongly Disagree

Table 6 above also indicates that the teachers agree on the feasibility of the MWebQuest created in terms of content. There are some suggestions given by the 
teachers associated with the improvement of M-WebQuest. The suggestions are related to combination of text, pictures and colors; choice of words for instructions; add some related materials; and more exercises given. For the perfection of the MWebQuest, all necessary improvements are made.

Evaluation from students: The formative evaluation also involving 30 students. The questionnaire used for evaluation from the students is the same as questionnaire used for evaluation from the teachers. The descriptive analysis of every aspect evaluated in the M-WebQuest evaluation can be seen in Tables 7 and 8 .

Table 7. Students' Evaluation in Terms of Technical

\begin{tabular}{|c|c|c|c|c|c|c|}
\hline \multirow[t]{3}{*}{ No } & \multirow[t]{2}{*}{ Aspects Evaluated } & \multicolumn{5}{|c|}{ Scales } \\
\hline & & $S A$ & $A$ & $N A D$ & $D A$ & $S D A$ \\
\hline & Interface Screen & & & & & \\
\hline 1 & The appearance is interesting & $\begin{array}{l}6 \text { students } \\
(20 \%)\end{array}$ & $\begin{array}{c}19 \text { students } \\
(63.3 \%)\end{array}$ & $\begin{array}{c}2 \text { students } \\
(6.7)\end{array}$ & $\begin{array}{c}3 \text { students } \\
(10 \%)\end{array}$ & $(0 \%)$ \\
\hline 2 & The colors used are appropriate & $\begin{array}{c}7 \text { students } \\
(23.3 \%) \\
\end{array}$ & \begin{tabular}{|c|}
$\begin{array}{c}18 \text { students } \\
(60 \%)\end{array}$ \\
\end{tabular} & \begin{tabular}{|c|}
5 students \\
$(16.7 \%)$ \\
\end{tabular} & $(0 \%)$ & $(0 \%)$ \\
\hline 3 & The size is suitable and easy to read & $\begin{array}{c}11 \text { students } \\
(36.7 \%)\end{array}$ & $\begin{array}{c}13 \text { students } \\
(43.3 \%)\end{array}$ & $\begin{array}{c}6 \text { students } \\
(20 \%)\end{array}$ & $(0 \%)$ & $(0 \%)$ \\
\hline 4 & Easy to learn anywhere & $\begin{array}{c}19 \text { students } \\
(63.3 \%)\end{array}$ & $\begin{array}{c}9 \text { students } \\
(30 \%)\end{array}$ & & \begin{tabular}{|c|}
2 students \\
$(6.7 \%)$
\end{tabular} & $(0 \%)$ \\
\hline \multirow[t]{2}{*}{5} & $\begin{array}{l}\text { Availability of instructions provides conven- } \\
\text { ience in learning }\end{array}$ & $\begin{array}{c}\text { students } \\
(23.3 \%)\end{array}$ & $\begin{array}{c}16 \text { students } \\
(53.3 \%)\end{array}$ & \begin{tabular}{|c|}
5 students \\
$(16.7 \%)$
\end{tabular} & $\begin{array}{c}2 \text { students } \\
(6.7 \%)\end{array}$ & $(0 \%)$ \\
\hline & Text & & & & & \\
\hline 1 & The text used is clear and easy to read & $\begin{array}{c}16 \text { students } \\
(53.3 \% \%\end{array}$ & $\begin{array}{c}8 \text { students } \\
(26.7 \%) \\
\end{array}$ & \begin{tabular}{|c|}
2 students \\
$(6.7 \%)$
\end{tabular} & \begin{tabular}{|c|}
4 students \\
$(13.3 \%)$ \\
\end{tabular} & $(0 \%)$ \\
\hline 2 & Integration of text is suitable & $\begin{array}{c}11 \text { students } \\
(36.7 \%)\end{array}$ & \begin{tabular}{|c|}
$\begin{array}{c}15 \text { students } \\
(50 \%)\end{array}$ \\
\end{tabular} & \begin{tabular}{|c|}
3 students \\
$(10 \%)$
\end{tabular} & \begin{tabular}{|c|}
1 student \\
$(3.3 \%)$
\end{tabular} & $(0 \%)$ \\
\hline 3 & Appearance of text can attract attention & $\begin{array}{c}16 \text { students } \\
(53.3 \%)\end{array}$ & \begin{tabular}{|c|}
14 students \\
$(46.7 \%)$
\end{tabular} & $(0 \%)$ & $(0 \%)$ & $(0 \%)$ \\
\hline 4 & $\begin{array}{l}\text { Combination of text, pictures and colors can } \\
\text { help students to understand the subject matter } \\
\text { more easily }\end{array}$ & $\begin{array}{c}17 \text { students } \\
(56.7 \%)\end{array}$ & $\begin{array}{c}13 \text { students } \\
(43.3 \%)\end{array}$ & $(0 \%)$ & $(0 \%)$ & $(0 \%)$ \\
\hline
\end{tabular}

$\mathrm{SA}=$ Strongly Agree; $\mathrm{A}=$ Agree NAD = Neither Agree nor Disagree; $\mathrm{DA}=$ Disagree SDA $=$ Strongly Disagree

In general, according to Table 7 above, the students agree on the feasibility of MWebQuest developed in terms of technical - the interface screen and text created. However, in some aspects it can be seen that the students are disagree. The students' evaluation on the feasibility of the M-WebQuest in terms of content can be seen in the following Table 8 . 
Table 8. Students' Evaluation in Terms of Content

\begin{tabular}{|c|c|c|c|c|c|c|}
\hline \multirow[t]{2}{*}{ No } & \multirow[t]{2}{*}{ Aspects Evaluated } & \multicolumn{5}{|c|}{ Scales } \\
\hline & & $S A$ & $A$ & $N A D$ & $D A$ & $S D A$ \\
\hline 1 & Content is easy to follow & $\begin{array}{c}10 \text { students } \\
(33.3 \%)\end{array}$ & $\begin{array}{c}16 \text { students } \\
(53.3 \%)\end{array}$ & $\begin{array}{c}2 \text { students } \\
(6.7 \%)\end{array}$ & \begin{tabular}{|c|}
2 students \\
$(6.7 \%)$
\end{tabular} & $(0 \%)$ \\
\hline 2 & $\begin{array}{l}\text { The content helps students understand the } \\
\text { needs of using M-WebQuest }\end{array}$ & $\begin{array}{l}8 \text { students } \\
(26.7 \%)\end{array}$ & $\begin{array}{c}19 \text { students } \\
(63.3 \%)\end{array}$ & $\begin{array}{c}2 \text { students } \\
(6.7 \%)\end{array}$ & $\begin{array}{c}1 \text { student } \\
(3.3 \%)\end{array}$ & $(0 \%)$ \\
\hline 3 & $\begin{array}{l}\text { Content helps students identify the } \\
\text { component of M-WebQuest menus involved } \\
\text { to complete the task }\end{array}$ & $\begin{array}{l}8 \text { students } \\
(26.7 \%)\end{array}$ & $\begin{array}{c}20 \text { students } \\
(66.6 \%)\end{array}$ & $\begin{array}{l}2 \text { students } \\
(6.7 \%)\end{array}$ & $(0 \%)$ & $(0 \%)$ \\
\hline 4 & $\begin{array}{l}\text { The content helps students draw concepts of } \\
\text { subject matter }\end{array}$ & $\begin{array}{c}6 \text { students } \\
(20 \%)\end{array}$ & $\begin{array}{l}24 \text { students } \\
(80.0 \%)\end{array}$ & $(0 \%)$ & $(0 \%)$ & $(0 \%)$ \\
\hline 5 & $\begin{array}{l}\text { Content is in line with the knowledge that } \\
\text { the student needs to achieve }\end{array}$ & $\begin{array}{l}4 \text { students } \\
(13.3 \%)\end{array}$ & $\begin{array}{l}23 \text { students } \\
(76.7 \%)\end{array}$ & $\begin{array}{l}3 \text { students } \\
(10.0 \%)\end{array}$ & $(0 \%)$ & $(0 \%)$ \\
\hline 6 & $\begin{array}{l}\text { Content is in line } r \\
\text { student needs to ac }\end{array}$ & $\begin{array}{l}9 \text { students } \\
(30.0 \%)\end{array}$ & $\begin{array}{c}20 \text { students } \\
(66.7 \%)\end{array}$ & $\begin{array}{l}1 \text { student } \\
(3.3 \%)\end{array}$ & $(0 \%)$ & $(0 \%)$ \\
\hline 7 & $\begin{array}{l}\text { The content is organized from easy into } \\
\text { difficult subject matter }\end{array}$ & $\begin{array}{c}14 \text { students } \\
(46.7 \%)\end{array}$ & $\begin{array}{c}13 \text { students } \\
(43.3 \%)\end{array}$ & $\begin{array}{c}3 \text { students } \\
(10.0 \%)\end{array}$ & $(0 \%)$ & $(0 \%)$ \\
\hline 8 & Examples provided are sufficient & $\begin{array}{l}9 \text { students } \\
(30.0 \%)\end{array}$ & $\begin{array}{c}17 \text { students } \\
(56.7 \%)\end{array}$ & $\begin{array}{l}4 \text { students } \\
(13.3 \%)\end{array}$ & $(0 \%)$ & $(0 \%)$ \\
\hline 9 & The explanation provided is complete & $\begin{array}{l}7 \text { students } \\
(23.3 \%) \\
\end{array}$ & $\begin{array}{c}18 \text { students } \\
(60.0 \%)\end{array}$ & \begin{tabular}{|c|}
5 students \\
$(16.7 \%)$
\end{tabular} & $(0 \%)$ & $(0 \%)$ \\
\hline 10 & $\begin{array}{l}\text { Activities provided are in line with the } \\
\text { objectives of learning }\end{array}$ & $\begin{array}{c}18 \text { students } \\
(60.0 \%)\end{array}$ & $\begin{array}{c}10 \text { students } \\
(33.3 \%)\end{array}$ & $\begin{array}{l}2 \text { students } \\
(6.7 \%)\end{array}$ & $(0 \%)$ & $(0 \%)$ \\
\hline 20 & $\begin{array}{l}\text { Exercises given are in line with the objec- } \\
\text { tives of learning }\end{array}$ & $\begin{array}{c}12 \text { students } \\
(40.0 \%)\end{array}$ & $\begin{array}{c}10 \text { students } \\
(33.3 \%)\end{array}$ & $\begin{array}{l}8 \text { students } \\
(26.7 \%)\end{array}$ & $(0 \%)$ & $(0 \%)$ \\
\hline 21 & $\begin{array}{l}\text { Encourages students to carry out sustainable } \\
\text { activities }\end{array}$ & $\begin{array}{c}10 \text { students } \\
(33.3 \%)\end{array}$ & $\begin{array}{c}18 \text { students } \\
(60.0 \%)\end{array}$ & $\begin{array}{l}2 \text { students } \\
(6.7 \%)\end{array}$ & $(0 \%)$ & $(0 \%)$ \\
\hline 22 & Provide appropriate steps & $\begin{array}{c}10 \text { students } \\
(33.3 \%)\end{array}$ & $\begin{array}{c}18 \text { students } \\
(60.0 \%)\end{array}$ & $\begin{array}{l}2 \text { students } \\
(6.7 \%)\end{array}$ & $(0 \%)$ & $(0 \%)$ \\
\hline 23 & Step provided are effective & $\begin{array}{c}9 \text { students } \\
(30 \%)\end{array}$ & $\begin{array}{c}20 \text { students } \\
(66.7 \%)\end{array}$ & $\begin{array}{l}1 \text { student } \\
(3.3 \%)\end{array}$ & $(0 \%)$ & $(0 \%)$ \\
\hline 24 & $\begin{array}{l}\text { Assessment provided is tailored to the learn- } \\
\text { ing objective }\end{array}$ & $\begin{array}{c}12 \text { students } \\
(40.0 \%)\end{array}$ & $\begin{array}{c}16 \text { students } \\
(53.3 \%)\end{array}$ & $\begin{array}{l}2 \text { students } \\
(6.7 \%)\end{array}$ & $(0 \%)$ & $(0 \%)$ \\
\hline 25 & The exercises available are appropriate & $\begin{array}{l}13 \text { students } \\
(43.3 \%)\end{array}$ & $\begin{array}{c}12 \text { students } \\
(40.0 \%)\end{array}$ & $\begin{array}{l}3 \text { students } \\
(10 \%)\end{array}$ & $\begin{array}{c}2 \text { students } \\
(6.7 \%)\end{array}$ & $(0 \%)$ \\
\hline
\end{tabular}

$\mathrm{SA}=$ Strongly Agree; $\mathrm{A}=$ Agree $\mathrm{NAD}=$ Neither Agree nor Disagree $\mathrm{DA}=$ Disagree SDA $=$ Strongly Disagree

Table 8 above indicates that majority of the students agree on the feasibility of the M-WebQuest in terms of its content. Anyway, there are also some suggestions given by the students, related to these aspects: hard to understand the content, needs more examples, and too much exercises to do, and types of exercises given. Afterwards, some improvements are made. Chang, et al. in [29], mentions that designing and implementing high quality of WebQuest has the quality to improve the students' learning process and performance. However, Alshammari in [22], claims that some teachers do not know how to create good quality WebQuests. But this does not mean that teachers are insufficient in implementing of WebQuests in teaching; they can use computer aided instructional strategies on how to apply WebQuest framework. Perizat, et al. in [23], explain that more accent on teachers afford should be made for the successful implementation of the WebQuest in teaching and learning process. 


\section{Conclusion}

This study has successfully elaborated the development process and succeeds to improve M-WebQuest that can be used for the learning activities of English reading comprehension for senior high school students Grade XI in Pekanbaru, Riau Indonesia. The findings indicate that the experts, teachers and students agree to the MWebQuest created. The weaknesses in the process of the M-WebQuest development have been updated in order that the M-WebQuest can reach the objective standard of student learning. The results of the M-WebQuest evaluation are successful to show that the M-WebQuest produced is appropriate to apply in learning activities.

\section{Acknowledgement}

This work is supported by Universitas Riau, Pekanbaru, Indonesia.

\section{$7 \quad$ References}

[1] Tuan, L.T. 2011. Teaching Reading through WebQuest. Journal of Language Teaching and Research. 2 (3): $664-673$.

[2] Mahdum. 2010. Efektifitas metode cooperative learning tipe CIRC dalam meningkatkan kemampuan membaca mahasiswa S1 semester satu program studi bahasa Inggris FKIP UR Pekanbaru. Jurnal Percikan 113(6), 107-114. https://doi.org/10.23917/varidika.v24i4.706

[3] Nordin N.M. \& Hong, N.C. 2009. Pembangunan dan Penilaian Bahan Pengajaran dan Pembelajaran Berasaskan Web-WebQuest bagi Mata Pelajaran ICT. Jurnal Pendidikan Malaysia 34 (1), 111-129. https://doi.org/10.21070/picecrs.v1i1.644

[4] Ayers, C.A. 2014. 21st century technology integration in secondary social studies education: Three constructivist, technology-based practices. The Oregon Journal of the Social Studies, 2(1), 85-97.

[5] Muhammad, A, Mursidin, T., \& Firdaus. 2008. Pemanfaatan Teknologi Informasi dan Komunikasi (TIK) dalam Pembelajaran di Provinsi Sulawesi Tenggara. Education Symposium 2008. South East Sulawesi.

[6] Dodge, B. (1995). WebQuests: A technique for internet-based learning. Distance educator, $1(2), 10-13$.

[7] Gokalp, M.S., Sharma, M., Johnston, I., \& Sharma, M. 2013. Implementing WebQuest based instruction on newton's second law. Teaching Science, 59(2), 11-22.

[8] Miralles, P.; Gómez, C. J., \& Arias, L. 2013. Social sciences teaching and information processing. An Experience Using WebQuests in Primary Education Teacher Training. Universities and Knowledge Society Journal, 10(2), 344. https://doi.org/10.7238/rusc.v10 $\underline{\mathrm{i} 2.1536}$

[9] Kurtulus, A., \& Ada, T. 2012. WebQuest on conic sections as a learning tool for prospe ctive teachers. Teaching Mathematics and its Applications: An International Journal of the IMA, 31(4), 215. https://doi.org/10.1093/teamat/hrs003

[10] March, T. 2008. What WebQuests are (Really). [http://bestwebquests.com/ what_web quests_are. asp]. Retrieved on December 27, 2015.

[11] Dodge, B. (2001). FOCUS: Five rules for writing a great WebQuest. Learning and leading with technology, 28(8), 6-9. 
[12] Lamb, A., \& Teclehaimanot, B. 2005. A decade of WebQuests: A retrospective. In M. Orey, J. McClendon, \& R. M. Branch, (Eds.). Educational media and technology yearbook (Vol 30). Englewood, CO: Libraries Unlimited.

[13] Turville, J.2008. Differentiating by Student Learning Preferences, Strategies and Lesson Plans. Eye on Education, Inc. https://doi.org/10.4324/9781315854694

[14] Gallego, D. and García, C. 2011. Educación, Sociedad y Tecnología (2a ed.). Madrid: Editorial Universitaria Ramón Areces DL.

[15] Awada, G., \& Ghaith, G. 2014. Impact of using the WebQuest technological model on English as a foreign language (EFL) writing achievement and apprehension. Arab World English Journal, 81-93.

[16] Hadriana. 2017. WebQuest Application to Improve English Writing Skill. International Journal of Software Engineering and Its Applications, 11(4), 61-68. https://doi.org/10. 14257/ijseia.2017.11.4.05

[17] Chuo, T-W.I. 2007. The Effects of the WebQuest Writing InstructionProgram on EFL Learners' Writing Performance, Writing Apprehension, and Perception. Teaching English as a Second or Foreign Language (TESL-EJ), 11 (3), 1-27

[18] Prapinwong, M. 2008. Constructivist language learning through WebQuests in EFL context: an exploratory study. Doctoral dissertation, Indiana University.

[19] Al-Shamisi A.S. 2016. The Effect of WebQuests on Grade 11 Reading Comprehension and Student Perceptions of WebQuests. American International Journal of Contemporary 6(1), 132-143

[20] Alias, N., DeWitt, D., \& Siraj, S. 2014. An evaluation of gas law WebQuest based on active learning style in a secondary school in Malaysia. Eurasia Journal of Mathematics, Science \& Technology Education, 10(3), 175-184. https://doi.org/10.12973/eurasia.2014. $\underline{1074 \mathrm{a}}$

[21] Abbitt, J., \& Ophus, J. 2008. What we know about the impacts of WebQuests: A review of research. Association for the Advancement of Computing in Education journal, 16(4), 441456.

[22] Alshammari, A.R. 2015. Effectiveness of Using Webquest To Teach Computer Science to Middle School Students In Saudi Arabia. A Master's Thesis. State University of New York.

[23] Perizat, B, et al,. 2016. A Web-Quest as a Teaching and Learning Tool. International Electronic Journal of Mathematics Education, 11(10), 3537-3549.

[24] Barack, L. (2011). WebQuest blossoms. School Library Journal, 51(9).

[25] Renau, M.L., and Pesudo, M. 2016. Analysis of the implementation of a WebQuest for learning English in a secondary school in Spain. International Journal of Education and Development using Information and Communication Technology, 12 (2), 26-49

[26] Yang, K. 2014. The WebQuest model effects on mathematics curriculum learning in elementary school students. Computers \& Education, 72, 158-166. https://doi.org/10. 1016/j.compedu.2013.11.006

[27] Dodge, B. 1995. Some thoughts about WebQuest. (online). http://webquest. sdsu.edu/ about_webquests.html

[28] Borg,W.R. \& Gall, M.D. 2003. Educational Research: An Introduction. New York: Longman.

[29] Chang, C., Chen, T., \& Hsu, W. 2011. The study on integrating WebQuest with mobile learning for environmental education. Computers \& Education, 57(1), 1228-1239. https://doi.org/10.1016/j.compedu.2010.12.005 


\section{Authors}

Hadriana Adanan holds a $\mathrm{PhD}$ in Resource and Information Technology from The National University of Malaysia. She is a lecturer in the Faculty of Teacher Training and Education, Riau University. Her areas of research interest include educational technology in English language teaching and Teaching English as a Foreign Language (TEFL). She has presented papers in national and international conferences on ICT in education. hadriana@unri.ac.id

Mahdum Adanan holds a $\mathrm{PhD}$ in Resource and Information Technology from The National University of Malaysia. He is a lecturer in the Faculty of Teacher Training and Education, Riau University. His areas of research interest include the use of Information and Communication Technology (ICT) in education and Teaching English as a Foreign Language (TEFL). He has presented papers in national and international conferences on ICT in education. mahdum@unri.ac.id

Tutut Herawan is a faculty member at Airlangga University, Indonesia. Formerly he is an associate professor at Department of Information Systems, University of Malaya. He received $\mathrm{PhD}$ degree in information technology in 2010 from Universiti Tun Hussein Onn Malaysia. He is a visiting researcher at Parallel and Distributed Computing Research Lab of Deakin University Australia. He is also a part-time lecturer in many universities in Indonesia. He has more than 14 years experiences as academic and successfully supervised five PhD students. He presently supervises 15 Master \& $\mathrm{PhD}$ students and has examined Master \& $\mathrm{PhD}$ Theses. He is the executive editor of Malaysian Journal of Computer Science (ISI JCR with IF 0.405). He has also guest edited many special issues in many reputable international journals. He has edited five Springer-series books and published more than 300 articles in various book chapters, international journals and conference proceedings which are indexed in Scopus database (with H-index 23). He is an active reviewer for more than 50 international journals including top flagships journal e.g. IEEE Transactions on Fuzzy Systems, Knowledge-Based Systems, Information Sciences, IEEE Access, and many more. He delivered more than 20 keynote addresses, invited workshop and seminars and has been actively served as a chair, co-chair, program committee member and coorganizer for numerous international conferences/workshops. He is the founding chair of SCDM \& DaEng conferences with are supported by the renowned publisher Advances in Intelligent System \& Computing and Lecture Notes in Electrical Engineering of Springer Verlag, respectively. His research area includes information retrieval and decision support in information systems. His research area includes Data Mining and Knowledge Discovery, Decision Support in Information System, Rough and Soft Set theory. *Corresponding Author: konsultan@fst.unair.ac.id

Article submitted 2019-04-08. Resubmitted 2019-06-02. Final acceptance 2019-06-08. Final version published as submitted by the authors. 